\title{
Effects of salinity, temperature and nutrients on growth, cellular characteristics and yessotoxin production of Protoceratium reticulatum
}

\author{
Karin Röder ${ }^{\mathrm{a}, *}$, Florian Matthias Hantzsche ${ }^{\mathrm{b}}$, Christina Gebühr $^{\mathrm{c}}$, Claudia Miene ${ }^{\mathrm{d}}$, Tina Helbig ${ }^{\mathrm{a}}$, \\ Bernd Krock $^{\mathrm{e}}$, Mona Hoppenrath ${ }^{\mathrm{f}}$, Bernd Luckas ${ }^{\mathrm{a}}$, Gunnar Gerdts ${ }^{\mathrm{c}}$ \\ a Institute for Nutrition, Department of Food Chemistry, Friedrich-Schiller-University of Jena, Dornburger Straße 25, D-07743 Jena, Germany \\ ${ }^{\mathrm{b}}$ GKSS Research Centre, Max-Planck-Straße 1, 21502 Geesthacht, Germany \\ ${ }^{\mathrm{C}}$ Biologische Anstalt Helgoland, Alfred-Wegener-Institute for Polar and Marine Research, POB 180, D-27498 Helgoland, Germany \\ ${ }^{\mathrm{d}}$ Institute for Nutrition, Department of Nutritional Toxicology, Friedrich-Schiller-University of Jena, Dornburger Straße 25, D-07743 Jena, Germany \\ 'Alfred-Wegener-Institute for Polar and Marine Research, Am Handelshafen 12, D-27570 Bremerhaven, Germany \\ ${ }^{\mathrm{f}}$ German Centre for Marine Biodiversity Research, Forschungsinstitut Senckenberg, Südstrand 44, D-26382 Wilhelmshaven, Germany
}

\section{A R T I C L E I N F O}

\section{Article history:}

Received 8 April 2011

Received in revised form 23 November 2011

Accepted 23 November 2011

Available online 5 January 2012

\section{Keywords:}

Carboxy yessotoxin

Chlorophyll $a$

Formation in dependency on nutrients

Gonyaulax grindleyi

Keto yessotoxin

LC-MS/MS analyses

Protoceratium reticulatum

Salinity and temperature

YTX

\begin{abstract}
A B S T R A C T
Protoceratium reticulatum as a producer of yessotoxin (YTX) and its analogues is common in several coastal environments. The YTX-producing strain of P. reticulatum, isolated from the German Bight (North Sea), was analysed to study toxin production under various autecological conditions. Experiments were carried out to investigate the influence of N/P ratio $(2.44(1 / 10 \mathrm{~N}), 24.36(\mathrm{f} / 2)$ and $243.65(1 / 10 \mathrm{P}))$, temperature $\left(15\right.$ and $\left.20^{\circ} \mathrm{C}\right)$, salinity $(5,10,15,20,25$ and 30) and growth phase on YTX formation, cell size and chlorophyll $a$ concentration.

P. reticulatum showed the highest growth at $15^{\circ} \mathrm{C}$ and higher salinities (25 and 30). In particular, higher temperature led to a reduced growth. The total YTX concentrations were higher at lower temperature. However, a clear correlation between salinity and YTX production was not observed at lower temperature. Furthermore, $1 / 10 \mathrm{P}$ and $\mathrm{f} / 2$ cultures exhibited the highest cell quota of YTX at the end of the stationary phase; a dramatic effect occurred at $15{ }^{\circ} \mathrm{C}$ in $1 / 10 \mathrm{P}$ media, when the toxicity increased to ten fold higher values. Slight variations of the composition of the YTX analogues under nutrient limitation were observable. In addition, the results indicate that $\mathrm{N}$-limitation cause a lower cell size, whereas P-limitation leads to a higher cell size; an influence of the salinity on cell size was also observable.
\end{abstract}

(c) 2012 Elsevier B.V. All rights reserved.

\section{Introduction}

Yessotoxin (YTX), a disulphated polyether toxin was first isolated by Murata et al. (1987) from digestive glands of Japanese scallops (Patinopecten yessoensis). Three species of dinoflagellates were identified as YTX producing organisms, these are Protoceratium reticulatum (Claparède \& Lachmann) Bütschli (syn.: Gonyaulax grindleyi) (Satake et al., 1997), Lingulodinium polyedrum (Stein) Dodge (syn.: Gonyaulax polyedra) (Tubaro et al., 1998; Draisci et al., 1999) and Gonyaulax spinifera (Claparède \& Lachmann) Diesing (Rhodes et al., 2006; Riccardi et al., 2009). Meanwhile, the production of YTX by the dinoflagellate P. reticulatum has been reported in New

\footnotetext{
* Corresponding author at: Department of Food Chemistry, Faculty of Biology and Pharmacy, Friedrich-Schiller-University of Jena, Dornburger Straß 25, D-07743 Jena, Germany. Tel.: +49 3641949 653; fax: +49 3641949652.

E-mail address: Karin.Roeder@uni-jena.de (K. Röder).
}

Zealand, Japan, Norway, UK, Canada, USA, Chile, Spain, Italy, and southern Africa Bay (Ciminiello et al., 2003; Finch et al., 2005; Krock et al., 2006, 2009; Paz et al., 2004, 2006, 2007; Ramstad et al., 2001; Samdal et al., 2004; Satake et al., 1997, 1999, 2006).

Different concentrations of YTX were found in cultures of dinoflagellates around the world. The toxicity of $P$. reticulatum reached from 0.9 to 79 pg YTX cell ${ }^{-1}$ (Eiki et al., 2005; Howard et al., 2008; MacKenzie et al., 1998; Mitrovic et al., 2005; Paz et al., 2004, 2007; Samdal et al., 2004; Satake et al., 1996, 1999), and the concentrations of YTX in L. polyedrum were up to $1.5 \mathrm{pg} \mathrm{YTX} \mathrm{cell}^{-1}$, and in G. spinifera up to $200 \mathrm{pg}$ YTX cell $^{-1}$ (Draisci et al., 1999; Howard et al., 2008; Paz et al., 2004; Ramstad et al., 2001; Rhodes et al., 2006; Tubaro et al., 1998). It seems that the principal toxin formed by $P$. reticulatum is YTX, even though some strains contained homoYTX as prominent analogue (Paz et al., 2008). From about 100 known YTX analogues only $40 \%$ are characterized concerning their exact chemical structure (Miles et al., 2004, 2005a, 2005b, 2006a, 2006b; Paz et al., 2008). Suzuki et al. (2007) 
reported on $P$. reticulatum strains isolated at different sites of Japanese coasts (e.g. Mutsu Bay and Okirai Bay) which produced 45,46,47-trinoryessotoxin (trinorYTX), 1-homoyessotoxin (homoYTX), 45,46,47-trinor-1-homoyessotoxin besides YTX. In some strains 42,43,44,45,46,47,55-heptanor-41-oxoyessotoxin (noroxoYTX enone; ketoYTX) was also detected, and some of those strains exhibited a percentage of YTX analogues near to $50 \%$ of the total YTX concentration (Suzuki et al., 2007).

Environmental conditions are important for the production of toxins by dinoflagellates. However, only few studies are published how environmental factors might affect the YTX formation of $P$. reticulatum. Gallardo Rodríguez et al. (2009) and Guerrini et al. (2007) reported about the requirements of macronutrients; the effect of micronutrients was investigated by Mitrovic et al. (2004) and some data are available on the influence of temperature and salinity on the YTX production (Guerrini et al., 2007).

Our investigations were directed on the elucidation of the effect of various growth factors on formation of YTXs in a strain of $P$. reticulatum from the North Sea (Helgoland Roads) for better assessment of the risk for toxic dinoflagellate events in the North Sea connected with climate change or eutrophication. Therefore, the isolated strain of $P$. reticulatum was cultured at different conditions concerning macronutrients, salinity and temperature.

\section{Materials and methods}

\subsection{Isolation and identification of P. reticulatum}

Net samples from surface water at Helgoland Roads, German Bight, North Sea, Germany, were collected during a taxonomic phytoplankton re-investigation project (Hoppenrath, 2004; Hoppenrath et al., 2009). $P$. reticulatum cells were isolated by micropipetting from a mixed net-sample in April 2003, washed in sterile fine-filtered seawater and maintained in $\mathrm{f} / 2$ medium (Guillard, 1975) in plastic Petri dishes. After culture establishment tissue flasks were used. The original culture is available at the German Centre of Marine Biodiversity Research, Wilhelmshaven, from M. Hoppenrath. The species was identified under the light microscope by its characteristic cell shape, size, and thecal ornamentation (Fig. 1a-c). The species identification was verified by scanning electron microscopy (Fig. 1d-j).

\subsection{Media preparation, culture conditions and determination of the cell growth}

The $P$. reticulatum strain was maintained in borosilicate flasks in $500 \mathrm{ml} \mathrm{f} / 2$ medium without silicate (Guillard, 1975) at 70$90 \mu \mathrm{mol} \mathrm{s}^{-1} \mathrm{~m}^{-2}, 14{ }^{\circ} \mathrm{C}$ and $12: 12 \mathrm{~h}$ light/dark regime in natural seawater with a salinity of 30 .

The influence of the salinity on the YTX production was estimated at six salt concentrations. Therefore, the natural seawater of the North Sea, which had the original salinity of 30, was diluted with fresh water (drinking water) to the following concentrations: 5,10 , 15,20 and 25 . These five dilutions and the natural seawater were prepared as f/2 media without silicate, described by Guillard (1975). For nutrient limitation $\mathrm{f} / 2$ media were prepared containing three compositions of nutrients. First nutrient sufficient $f / 2$ medium (referred as $\mathrm{f} / 2$ ) containing the original concentration of nutrients, second $\mathrm{f} / 2$ medium with ten times less phosphorus $(1 / 10 \mathrm{P})$ and third $\mathrm{f} / 2$ medium with ten times less nitrogen $(1 / 10 \mathrm{~N}$ )(Table 1$)$. The $\mathrm{pH}$-value was adjusted to $7.6 \pm 0.02 \mathrm{using} \mathrm{HCl}$ and the media were incubated in thermo stated rooms at $15^{\circ} \mathrm{C}$ and $20^{\circ} \mathrm{C}$, respectively. The light/dark regime and the light intensity were retained unchanged. The strain was not pre-adapted to the changed conditions.

Three replicates of each were incubated in Erlenmeyer flasks (1 1 ) which were inoculated with $1 \mathrm{ml}$ of a late exponential stock culture of $P$. reticulatum and contained 11 cells $\mathrm{ml}^{-1}$ on day of inoculation. In addition, we took $10 \mathrm{ml}$ of the inoculum for toxin determination $(n=3)$. Therefore, the subsamples were filtered through GF/C filters (Carl Roth GmbH \& Co., Germany) under slight vacuum pressure.

The growth curves were determined by measurement of the in vivo fluorescence followed by successive cell counting of $P$. reticulatum in 3-day intervals $(n=3) .1 \mathrm{ml}$ of the culture was immediately measured by a fluorescence spectrophotometer (Cary Eclipse, Varian Inc., USA) using an excitation wavelength of $485 \mathrm{~nm}$ and an emission wavelength of $685 \mathrm{~nm}$. In addition, cells were counted using a Sedgewick-Rafter cell with a light microscope ( $10 \times$ objective), a minimum of 400 cells were counted. Specific growth rate $\left(\mu \mathrm{m}\left[\mathrm{day}^{-1}\right]\right)$ was calculated using the equation by Guillard (1973):

$\mu=\frac{\ln N_{1}-\ln N_{0}}{t_{1}-t_{0}}$

$N$ is cell density at a given time (t).

\subsection{Sampling in the exponential and the stationary growth phase}

For further analyses additional samples were taken in the exponential and stationary growth phase. Chlorophyll $a$ concentration was determined using subsamples of $25 \mathrm{ml}$ which were analysed as triplicate in vivo by the multialgal fluorimeter (BBE Moldaenke, Germany). This fluorometer allows determination of different algae classes: green (chlorophyceae), blue-green (cyanophyceae), brown (diatoms and dinophyceae) and cryptophyceae. The emission of the pigments after excitation at characteristic wavelengths was measured. Thus, the chlorophyll $a$ concentration and other pigments $\left(\mu \mathrm{g} \mathrm{l}^{-1}\right)$ were determined for all living cells.

For determination of cell size and morphology, subsamples of $50 \mathrm{ml}$ were analysed using the Flow CAM (Fluid Imaging Technologies, USA, further details see Sieracki et al., 1998). For most of the samples, depending on cell density, a minimum of 400 cells were measured. Particles from 5 to $100 \mu \mathrm{m}$ were measured using a $20 \times$ objective and a flow cell of $100 \mu \mathrm{m}$ in depth. Consequently, information about the cell diameter, volume, length and width of each measured cell were obtained.

The YTX concentration was determined by LC-MS/MS (see below).

\subsection{Extraction of yessotoxins and measurement by LC-MS/MS}

Cultures were filtered on GF/C filter (Whatman, GB) under slight vacuum, $100 \mathrm{ml}$ in the exponential growth phase and $300 \mathrm{ml}$ in the stationary phase, respectively. Filters were extracted with methanol $(\mathrm{MeOH})$ using an ultrasonic probe for $30 \mathrm{~s}$ and an icecooled ultrasonic bath for $30 \mathrm{~min}$, afterwards they were centrifuged at $14,000 \times g$ for $10 \mathrm{~min}$. The supernatant was stored and the filters were extracted again with $\mathrm{MeOH}$ using the ultrasonic bath ( $30 \mathrm{~min}$ ), followed by centrifugation at $14,000 \times \mathrm{g}$ for $10 \mathrm{~min}$. Supernatants were combined evaporated to dryness using a heating block $\left(40^{\circ} \mathrm{C}\right)$ under nitrogen stream. Dried samples were dissolved in $1 \mathrm{ml} \mathrm{MeOH}$, admitted to $2 \mathrm{ml}$ single-use syringes and filtered through $0.45 \mu \mathrm{m}$ nylon filters (Carl Roth GmbH \& Co., Germany).

$100 \mathrm{ml}$ of the culture filtrates were stored in $100 \mathrm{ml}$ flasks (Kautex, Germany) for measuring of released YTX in the culture media. The flasks were stored at $-20^{\circ} \mathrm{C}$ until further purification. Subsequently, the filtrates were loaded on prepared Chromabond C18ec cartridges (Macherey-Nagel GmbH \& Co. KG, Germany). Those were equilibrated with $3 \mathrm{ml} \mathrm{MeOH}$ and $3 \mathrm{ml}$ of deionised 

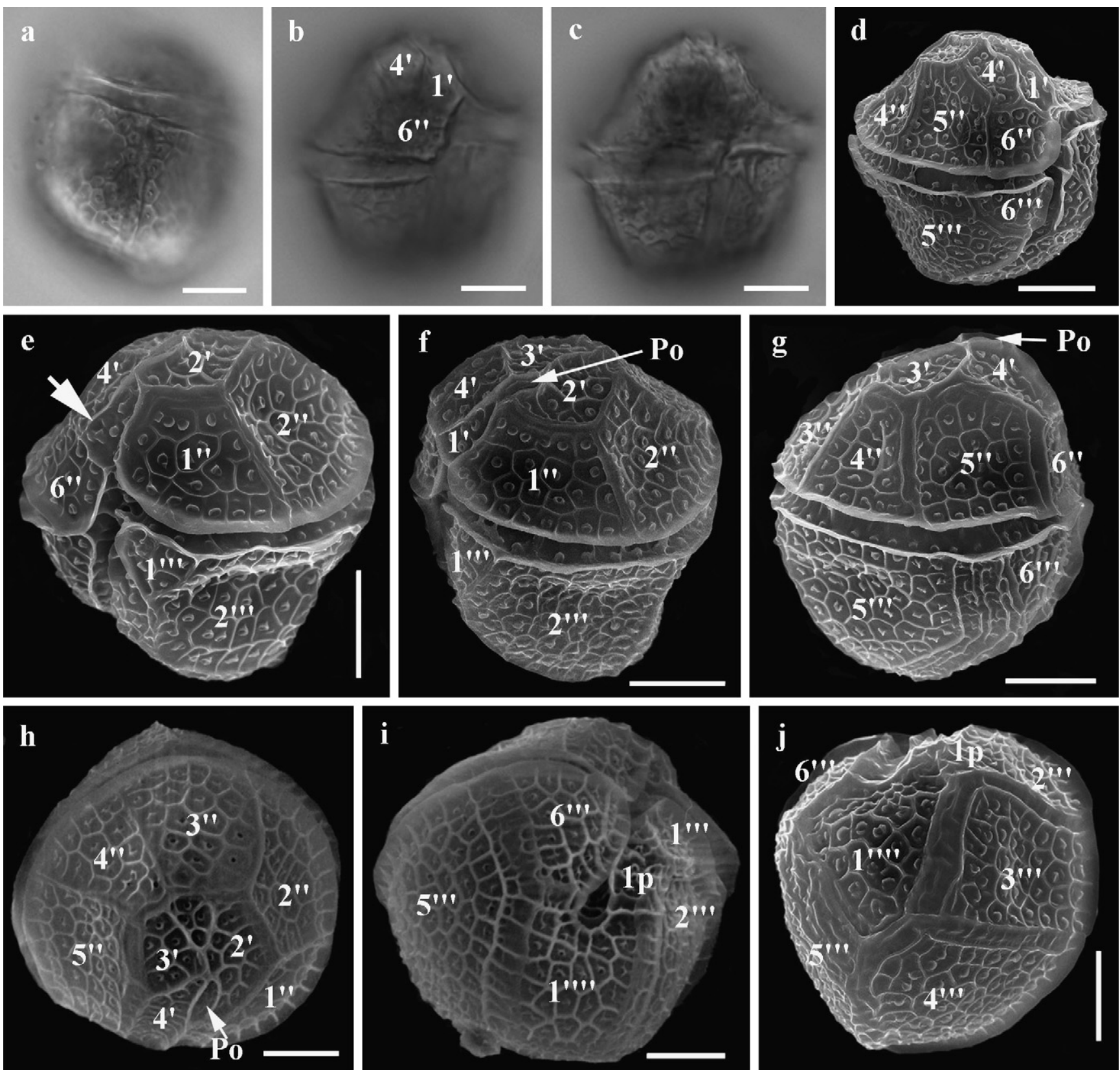

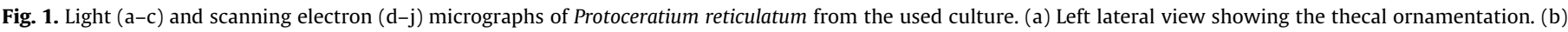

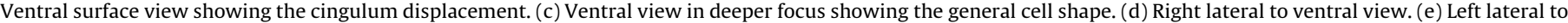

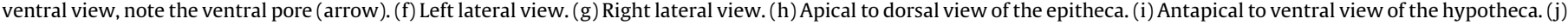
Antapical to left lateral view of the hypotheca. Scale bars $=10 \mu \mathrm{m}$.

water (Synergy Water Purification System, Millipore). Afterwards the culture filtrates $(100 \mathrm{ml})$ were loaded on the cartridge, washed with $3 \mathrm{ml}$ of deionised water and then eluted with $3 \mathrm{ml} \mathrm{MeOH}$. The $\mathrm{MeOH}$ was evaporated to dryness under nitrogen stream and samples were dissolved in $1 \mathrm{ml} \mathrm{MeOH}$ and filtered through $0.45 \mu \mathrm{m}$ nylon filters. All samples were stored at $-20{ }^{\circ} \mathrm{C}$ in brown autosampler vials until measuring by LC-MS/MS.

Table 1

Molar concentration and proportion of macronutrients in the final media.

\begin{tabular}{llll}
\hline \multirow{2}{*}{ Component } & \multicolumn{4}{l}{ Molar concentration in final media } \\
\cline { 2 - 4 } & Control & $1 / 10 \mathrm{~N}$ & $1 / 10 \mathrm{P}$ \\
\hline $\mathrm{NO}_{3}{ }^{-}$ & $8.82 \times 10^{-4} \mathrm{M}$ & $0.882 \times 10^{-4} \mathrm{M}$ & $8.82 \times 10^{-4} \mathrm{M}$ \\
$\mathrm{PO}_{4}{ }^{3-}$ & $3.62 \times 10^{-5} \mathrm{M}$ & $3.62 \times 10^{-5} \mathrm{M}$ & $0.362 \times 10^{-5} \mathrm{M}$ \\
$\mathrm{N} / \mathrm{P}$ & 24.36 & 2.44 & 243.65 \\
\hline
\end{tabular}

Certified YTX standard solution, dissolved in $\mathrm{MeOH}$, was obtained from the National Research Council (NRC) Canada (Halifax, Canada). The LC-MS/MS measurements were carried out as described earlier (Röder et al., 2011). Liquid chromatography was performed using Hyperclone C8 Column $(3 \mu \mathrm{m}, 130 \AA$, $50 \times 2.0 \mathrm{~mm}$ ) with security guard (Phenomenex, Germany) by gradient elution at a flow of $0.3 \mathrm{ml} \mathrm{min}{ }^{-1}$. Mobile phase consists of eluent A: $5 \mathrm{mM}$ ammonium formate in acetonitrile/water (10:90) and of eluent B: $5 \mathrm{mM}$ ammonium formate in acetronitrile/water (90:10). The gradient elution was done with $100 \%$ A for $1.5 \mathrm{~min}$, followed by linear gradient to $40 \%$ A over $3.5 \mathrm{~min}$, held over $5.0 \mathrm{~min}$, and within $1.0 \mathrm{~min}$ to $100 \% \mathrm{~B}$, held for $9.0 \mathrm{~min}$ and at least within 1.0 min back to $100 \% \mathrm{~A}$, held for $24 \mathrm{~min}$.

MS/MS analyses were performed using a Triple Quadrupole API 365 LC-MS/MS (Applied Biosystems GmbH, Germany) with electrospray ionization by ESI Turbo Ion spray Interface (SCIEX, 
Canada). Analyses were carried out in multi reaction monitoring (MRM) mode with negative ionization; selected transitions $\left([\mathrm{M}-\mathrm{H}]^{-}>\left[\mathrm{M}-\mathrm{H}-\mathrm{SO}_{3}\right]^{-}:\right.$YTX $\mathrm{m} / z 1141.5>1061.5$, homoYTX $m / z 1155.5>1075.5$, 45-OH-YXT $m / z 1157.5>1077.5$, carboxyYTX $\mathrm{m} / \mathrm{z} 1173.5>1093.5$, the putative $45-\mathrm{OH}$-carboxyYTX $\mathrm{m} / \mathrm{z}$ $1189.8>1109.5, \mathrm{~m} / z 1047.5>967.5$ (probably ketoYTX) and $m / z$ $1191.5>1111.5$ ). YTX concentrations were determined by a three point calibration curve using dilutions of a certified YTX standard solution (NRC, Halifax, Canada). Concentrations of the YTX analogues were expressed as YTX equivalents.

Statistical analyses were performed using GraphPad Prism 5.01 (GraphPad Software, Inc., San Diego, CA). 1-way ANOVA was applied for analysis of variances of cell size, chlorophyll $a$ concentration, and YTX cell quota between media with a salinity of $15,20,25$, and 30 , as well as between $\mathrm{f} / 2,1 / 10 \mathrm{~N}$ media, and $1 / 10$ $P$ media. 2-Way ANOVA was applied to compare variances of chlorophyll $a$ concentration and YTX cell quota at the different salinities in the exponential versus stationary growth phase. Both, 1-way and 2-way ANOVA included Bonferroni's multiple comparison test as post test. $P$ values $<0.05$ were considered as significant.

\section{Results}

\subsection{Identification of P. reticulatum}

Chloroplasts color the cells golden-brown. The cingulum is nearly median and descending about one cingular width without overlap (Fig. 1b and c). Cells are slightly laterally compressed. $P$. reticulatum is photosynthetic, has a strongly ornamented theca (Fig. $1 \mathrm{~d}-\mathrm{j}$ ) and this characteristic reticulation with one or two pores inside each reticulation subunit can hide the sutures so that it can be difficult to recognize the plate borders. The plate pattern was discerned as Po $4^{\prime} 6^{\prime \prime} 6^{\prime \prime \prime} 1 \mathrm{p} 1^{\prime \prime \prime \prime}$ as has been described before (Fig. 1d-j; Woloszynska, 1928; Hansen et al., 1997). Some cells had a different epithecal plate pattern with $3^{\prime}$ and $1 \mathrm{a}$, this variability is also known from the literature (Von Stosch, 1969; Hansen et al., 1997). The first apical plate has a ventral pore at its right margin (Fig. 1e). The pore plate is narrow and elongated (Fig. 1f-h). For further information see Section 2.

\subsection{Growth of $P$. reticulatum}

$P$. reticulatum cells cultured at a salinity of 5 and 10 died in all cases short time after inoculation. Highest cell concentration was observed in the $\mathrm{f} / 2$ media at $15{ }^{\circ} \mathrm{C}$ at salinities of 25 and 30 Culturing at a salinity of 20 or below decreased the growth strongly (Fig. 2a). Furthermore, $1 / 10 \mathrm{~N}$ cells cultivated at $15^{\circ} \mathrm{C}$ reached the stationary phase faster than those cultured in $\mathrm{f} / 2$ media and the absolute cell number was also lower. The influence of the salinity on growth in $1 / 10 \mathrm{~N}$ media was not so high; cells cultured at salinities of 20, 25 and 30 had almost the same maximum of cells (Fig. 2c). P. reticulatum cultivated in 1/10 $\mathrm{P}$ media reached the stationary phase faster than cells cultivated in the $\mathrm{f} / 2$ media and in the 1/10 P media, with low growth at salinities of 20,25 and 30 and lowest growth at a salinity of 15 (Fig. 2e).

The same influence of the salinity on growth of $P$. reticulatum was observed in $\mathrm{f} / 2$ media at both temperatures of 15 and $20^{\circ} \mathrm{C}$, but the maximum cell counts were higher at $15^{\circ} \mathrm{C}$ (Fig. 2a and b). Higher temperature caused no differences in growth between $1 /$ $10 \mathrm{~N}$ cultures at 15 and $20^{\circ} \mathrm{C}$, except for cells cultured at a salinity of 15 showed a higher growth rate at $15^{\circ} \mathrm{C}$. Also the growth of $1 / 10$ P cultures was low at 15 and $20^{\circ} \mathrm{C}$ (Fig. $2 \mathrm{C}$ and f). Growth rates in the exponential growth phase ranged from 0.21 to 0.35 day $^{-1}$.

\subsection{Variation of cell size and morphology}

The influence of nutrient limitation, salinity and temperature on cell size and morphology was investigated; therefore characteristics of $P$. reticulatum during exponential and stationary phase were compared. No changes of cell size or morphology were found in $\mathrm{f} / 2$ media at a salinity of 30 . Thus, this culture acts as reference to compare the influence of nutrient limitation and salinity. The strongest changes of the cell size depending on nutrient limitation and salinity were observed in the stationary phase, but a trend was already visible in the exponential growth phase (data not shown). In general an increase of cell size during culturing was observed in the $\mathrm{f} / 2$ media at salinities of 15,20 , and 25 and in 1/10 P media (all salinities), whereas the cell size was highest in low salinity cultures in the stationary phase; compared to cells cultured in $\mathrm{f} / 2$ media at a salinity of 30 significant differences were observed $(P<0.001)$. The influence of salinity on the cell size was highest in the $\mathrm{f} / 2$ media. The lowest cell sizes were observed in cultures with $1 / 10 \mathrm{~N}$ media, whereas the difference to cells cultured in $\mathrm{f} / 2$ medium at a salinity of 30 was significant for $1 /$ $10 \mathrm{~N}$ media at salinities of 20,25 , and $30(P<0.001)$ and not significant at a salinity of $15(P>0.05)$. But comparing $1 / 10 \mathrm{~N}$ cells of different salinities with each other no statistic significance was observed for salinities of 20,25 , and 30 suggesting that the influence of salinity is less important. Fig. 3 shows the volume ( $f \mathrm{l})$ of $P$. reticulatum $\left(15^{\circ} \mathrm{C}\right)$ cultured at different salinities in the stationary phase, $P$ values in between the salinities were plotted. Statistic differences to cells cultured in $\mathrm{f} / 2$ at a salinity of 30 were only plotted for $1 / 10 \mathrm{~N}$ at a salinity of 15 . A similar pattern was also observed at $20^{\circ} \mathrm{C}$, even if the differences in between limitations or within one limitation between the salinities were not that clear. Statistic analyses of variances of cells cultured at $20^{\circ} \mathrm{C}$ in the stationary growth period revealed that there were significant differences comparing cells cultured in $\mathrm{f} / 2$ media at a salinity of 30 salinity and almost all other samples $(P<0.001)$; only ells cultured at a salinity of 25 were not statistically different. It was evident that cells cultured at higher temperature showed strong changes of morphology in the stationary phase. Those cells were deformed and showed excrescences.

\subsection{Chlorophyll a concentration}

Differences of chlorophyll $a$ cell quota were observed in $P$. reticulatum. Influence of the salinity: Generally, the concentrations of chlorophyll $a$ cell $^{-1}$ increased with lower salinity in $\mathrm{f} / 2$ and $1 / 10$ $P$ cultures. This effect was strongest at $15^{\circ} \mathrm{C}$ in the exponential growth phase. Significant differences were observed comparing $\mathrm{f} / 2$ cells cultured at a salinity of 30 to $25(P<0.01)$, and to 15 $(P<0.001)$. No statistic differences were observed comparing $\mathrm{f} / 2$ cells at a certain salinity to the next higher salinity (e.g. salinity of 15 vs. salinity of 20). Furthermore, differences between f/2 cultured cells of the exponential to the stationary growth phase were not statistically significant (Fig. 4a). The influence of the salinity on the chlorophyll $a$ concentration of $1 / 10 \mathrm{P}$ cultured $P$. reticulatum was less obvious. Significant differences only exist between $1 / 10$ P cells cultured at a salinity of 30 to 15 . Comparing cells of a certain salinity to the next higher salinity (salinity of 15 and 20) were statistically different $(P<0.001$, Fig. 4c). In the stationary phase differences exist between $\mathrm{f} / 2$ cells cultured at a salinity of 15 to salinity of 20 and to salinity of 30 ( $P<0.01$, Fig. $4 c$ ), respectively. No significant difference exists between 1/10 $\mathrm{P}$ cultured $P$. reticulatum cells. No correlation between salinity and chlorophyll $a$ concentration was observed in 1/10 P cultured cells $(P>0.05)$.

Influence of nutrients: No statistic significant difference exists between $P$. reticulatum cells cultured at $15^{\circ} \mathrm{C}$ in $\mathrm{f} / 2$ and $1 / 10 \mathrm{P}$ 


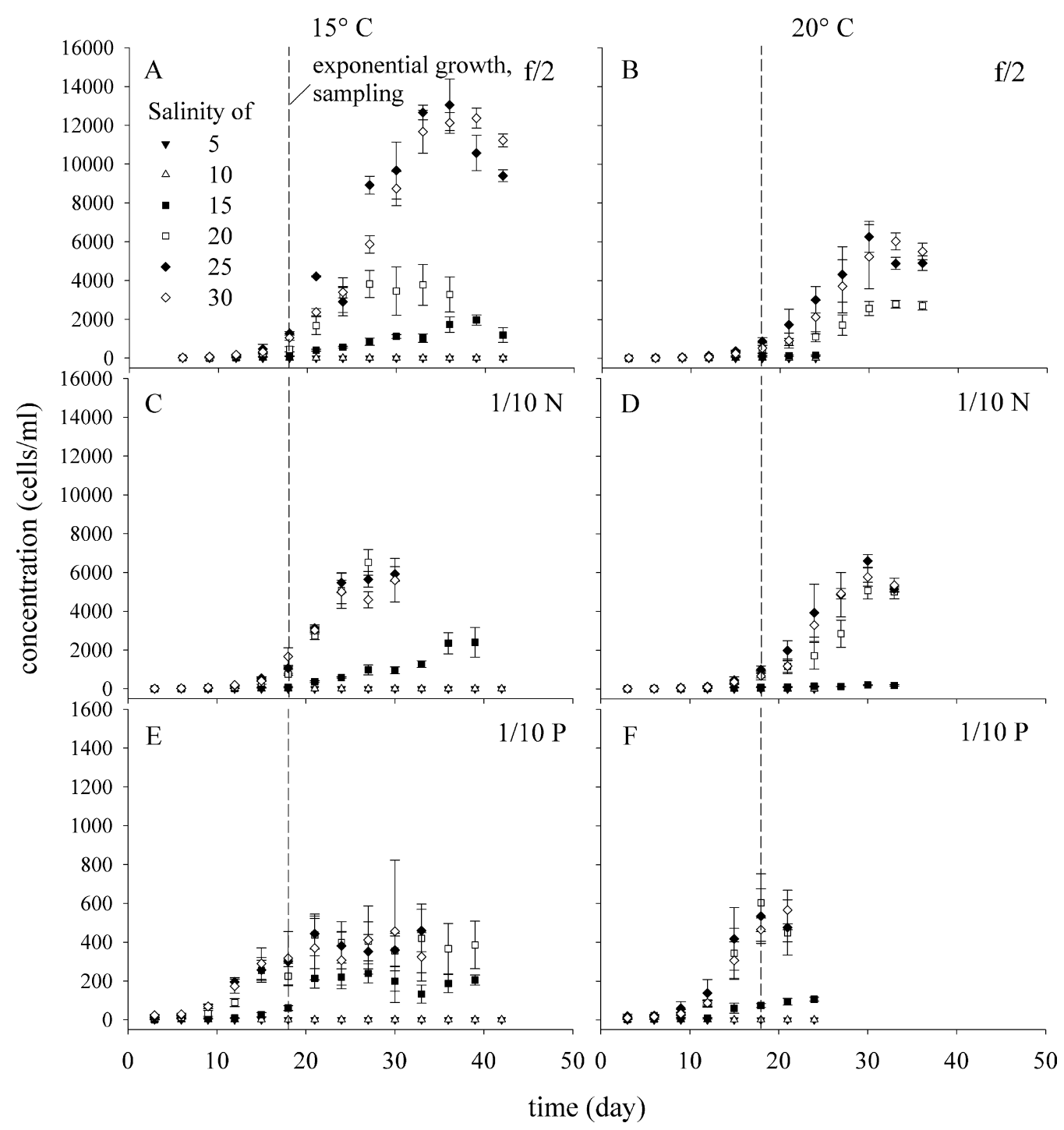

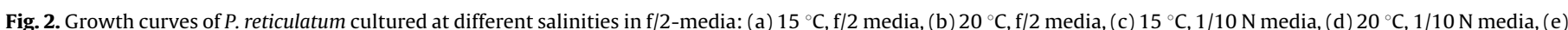

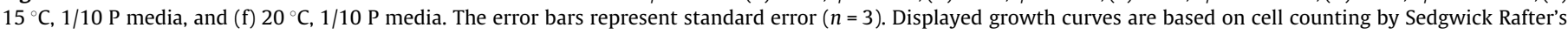
counting chamber.

media $(P>0.05)$. But the differences of $\mathrm{f} / 2$ and $1 / 10 \mathrm{P}$ to $1 / 10 \mathrm{~N}$ cultures were evident, especially in the stationary phase in which $\mathrm{f} /$ 2 and 1/10 $P$ cultured cells differ from $1 / 10 \mathrm{~N}$ cultured cells at: salinity of 15 (f/2: $P<0.001,1 / 10 P: P<0.001)$, salinity of $20(\mathrm{f} / 2$ : $P<0.05,1 / 10 \mathrm{P}: P<0.001)$, and salinity of $25(\mathrm{f} / 2: P<0.001)$. Only differences between $1 / 10 \mathrm{P}$ and $1 / 10 \mathrm{~N}$ at a salinity of 25 , and between $\mathrm{f} / 2$ as well as $1 / 10 \mathrm{P}$ and $1 / 10 \mathrm{~N}$ at a salinity of 30 were not significant $(P>0.05)$.

Influence of growth phase was most evident in $1 / 10 \mathrm{~N}$ limited cultures at $15{ }^{\circ} \mathrm{C}$ (Fig. 4b). There were no significant differences in the exponential growth phase at $20^{\circ} \mathrm{C}$, neither regarding the different salinities nor nutrients. In the stationary phase $P$. reticulatum cultured at a salinity of 20 contained significant more chlorophyll $a$ when cultured in $\mathrm{f} / 2$ medium than in $1 / 10 \mathrm{P}$ medium $(P<0.01)$. Furthermore cells cultured in $1 / 10 \mathrm{~N}$ medium at a salinity of 15 contained significant more chlorophyll $a$ in comparison to salinities of 20,25 , and $30(P<0.001$, respectively).

To exclude the potential influence of cell size on the chlorophyll $a$ concentration, the ratio of diameter to chlorophyll $a$ concentration was also calculated and the pattern did not change.

\subsection{YTX concentration in P. reticulatum cells}

YTX was the main analogue with a relative amount of more than $94 \%$ of all YTXs and a total concentration of $7.22 \pm 0.20 \mathrm{pg}$ YTX cell $^{-1}$ in the late exponential stock culture of $P$. reticulatum. In addition, low amounts of the putative carboxyYTX $(0.22 \pm 0.05 \mathrm{pg}$ YTX eq. cell $\left.{ }^{-1}\right)$ and the putative ketoYTX $(0.19 \pm 0.05 \mathrm{pg}$ YTX eq. cell ${ }^{-1}$ ) were detected in the inoculum.

The YTX cell quotas of $P$. reticulatum cultured at $15^{\circ} \mathrm{C}$ (in $\mathrm{f} / 2$ media at different salinities) were not homogenous in the exponential growth phase. The concentrations of YTX in cells cultured in $\mathrm{f} / 2$ media at lower salinities increased slightly from $7.22 \pm 0.20 \mathrm{pg}$ YTX cell $^{-1}$ (inoculum) to $10.28 \pm 3.45 \mathrm{pg} \mathrm{YTX} \mathrm{cell}^{-1}$ (salinity of 15) and to $8.41 \pm 2.09 \mathrm{pg} \mathrm{YTX} \mathrm{cell}^{-1}$ (salinity of 20). On the other hand, the concentrations of YTX, cultured in the same medium at higher salinities, decreased during the exponential growth phase from $7.22 \pm 0.20 \mathrm{pg}$ YTX cell $^{-1} \quad$ (inoculum) to $3.90 \pm 0.32 \mathrm{pg}$ YTX cell $^{-1}$ (salinity of 25) and to $4.02 \pm 0.68 \mathrm{pg} \mathrm{YTX} \mathrm{cell}^{-1}$ (salinity of 30). Compared to the inoculum differences of the YTX cell quota were not statistically significant $(P>0.05)$ (Fig. 5a).

A decrease of the YTX cell quota in the exponential growth phase with increasing salinity was also observed in $1 / 10 \mathrm{~N}$ media. 


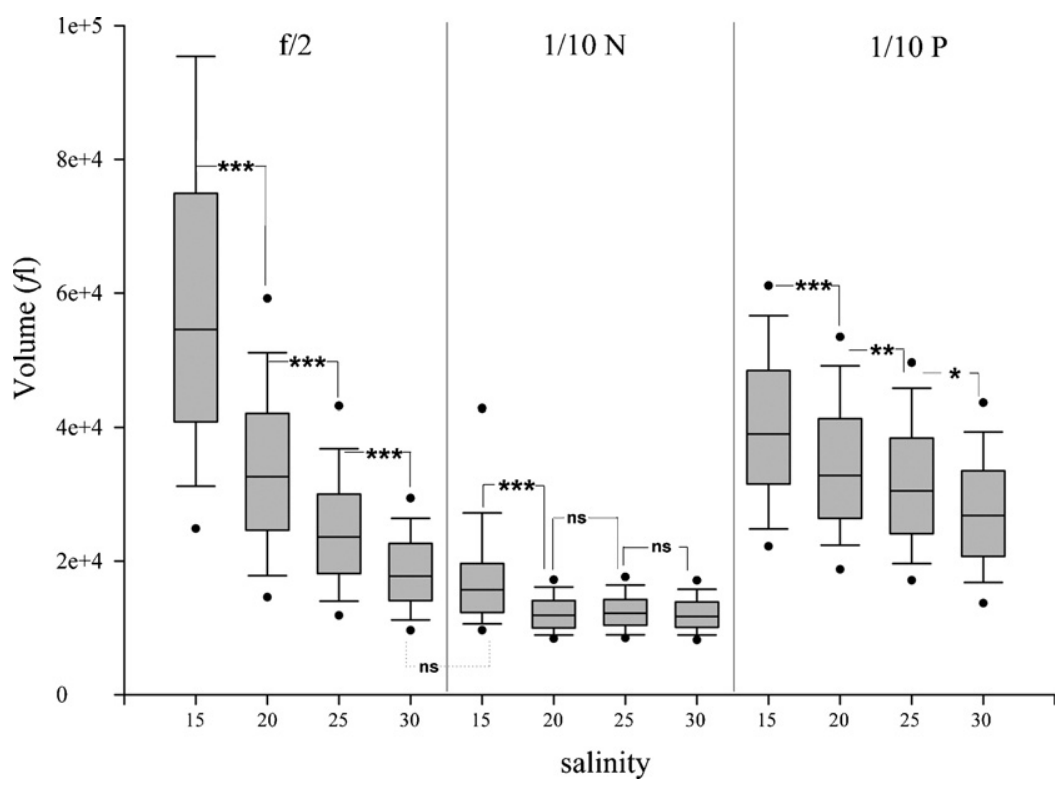

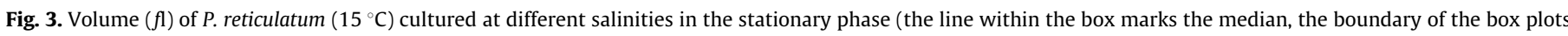

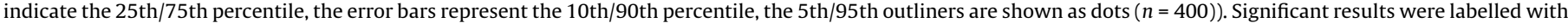
asterisks: ${ }^{*} P<0.05,{ }^{* *} P<0.01,{ }^{* * *} P<0.001$.

The concentrations of YTX in respective cells were generally lower compared to the YTX concentration in cells of the late exponential inoculum. Only cells cultured at a salinity of 15 contained a higher YTX cell quota $\left(13.51 \pm 2.01 \mathrm{pg}\right.$ YTX cell $\left.{ }^{-1}\right)$. With higher salinity the YTX concentrations decreased subsequently to $6.98 \pm 0.94 \mathrm{pg}$ YTX cell $^{-1}$ (salinity of 20), $6.43 \pm 1.21 \mathrm{pg}$ YTX cell $^{-1}$ (salinity of 25 ) and $4.14 \pm 1.28 \mathrm{pg} \mathrm{YTX} \mathrm{cell}^{-1}$ (salinity of 30 ). Compared to the inoculum differences of the YTX cell quota were not statistically significant $(P>0.05)$ (Fig. 5a).

However, the highest YTX concentrations cell $^{-1}$ in the exponential growth phase were observed in cultures in $1 / 10 \mathrm{P}$ media. The YTX concentrations tended to decrease by higher salinity also in those cultures. The YTX concentrations in the 1/10 P cultivated cells were: $24.13 \pm 4.08 \mathrm{pg} \mathrm{YTX} \mathrm{cell}^{-1}$ (salinity of 15), $25.29 \pm 6.63 \mathrm{pg}$ YTX cell $^{-1}$ (salinity of 20), $19.38 \pm 3.15 \mathrm{pg} \mathrm{YTX} \mathrm{cell}^{-1}$ (salinity of 25 ) and $17.13 \pm 1.28 \mathrm{pg} \mathrm{YTX} \mathrm{cell}^{-1}$ (salinity of 30 ). Compared to the inoculum differences of YTX cell quota were statistically significant for $1 / 10$ P cultured $P$. reticulatum at a salinity of $15(P>0.01)$ and a salinity of $20(P>0.001)$. Differences between the YTX cell quota of the inoculum to salinities of 25 and 30 were not significant $(P>0.05)$ (Fig. 5a).

The influence of the salinity on the YTX cell quota which was mentioned above was not significant in all media $(P>0.05)$.
In contrast to the YTX concentrations during the exponential growth phase, a different pattern was observed during the stationary phase. The YTX concentration in P. reticulatum cultured in $f / 2$ media in the stationary phase was higher than the YTX concentration during the exponential growth phase, with significant differences comparing salinities of $20(P<0.05), 25(P<0.01)$, and $30(P<0.01)$. $P$. reticulatum cells cultured at salinities of 15 and 20 had almost the same YTX concentration $14.23 \pm 1.51 \mathrm{pg}$ YTX cell $^{-1}$ (salinity of 15 ), $15.39 \pm 2.71 \mathrm{pg} \mathrm{YTX} \mathrm{cell}^{-1}$ (salinity of 20) and at salinities of 25 and 30 with YTX concentrations $11.28 \pm 0.77 \mathrm{pg}$ YTX cell $^{-1}$ (salinity of 25 ) and $11.53 \pm 1.81 \mathrm{pg}$ YTX cell $^{-1}$ (salinity of 30 ). Cells cultured in $1 / 10 \mathrm{~N}$ media contained less YTX cell ${ }^{-1}$ compared to the inoculum of late exponential $P$. reticulatum; $6.27 \pm 3.71 \mathrm{pg}$ YTX cell $^{-1}$ (salinity of 15$), 4.56 \pm 1.33 \mathrm{pg}$ YTX cell $^{-1}$ (salinity of 20), $5.89 \pm 0.42$ pg YTX cell $^{-1}$ (salinity of 25 ), and $5.12 \pm 1.15 \mathrm{pg} \mathrm{YTX} \mathrm{cell}^{-1}$ (salinity of 30 ). Differences between the inoculum and $\mathrm{f} / 2$ and $1 / 10 \mathrm{~N}$ media were not significant $(P>0.05)$ (Fig. 5b).

Otherwise, 1/10 P media cultures contained extremely high YTX concentrations: $50.66 \pm 3.27 \mathrm{pg}^{\text {YTX cell }}{ }^{-1}$ (salinity of 15 ), $50.06 \pm 19.49 \mathrm{pg}$ YTX cell $^{-1}$ (salinity of 20 ), $56.53 \pm 19.40 \mathrm{pg}$ YTX cell $^{-1}$ (salinity of 25 ) and $46.42 \pm 3.97$ pg YTX cell $^{-1}$ (salinity of 30) (Fig. 5b). All of them were significant different compared to the
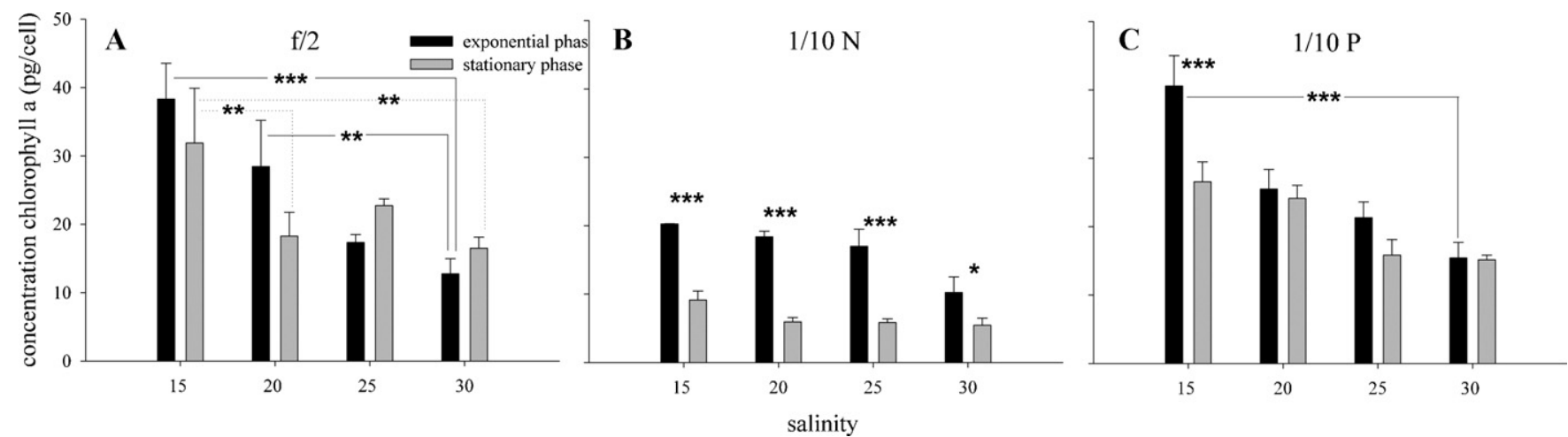

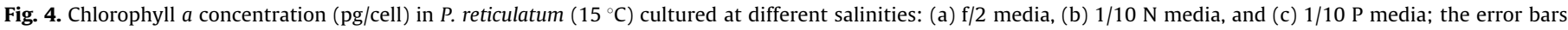
represent standard error $(n=3)$. Significant results were labelled with asterisks: ${ }^{*} P<0.05,{ }^{* *} P<0.01,{ }^{* * *} P<0.001$. 


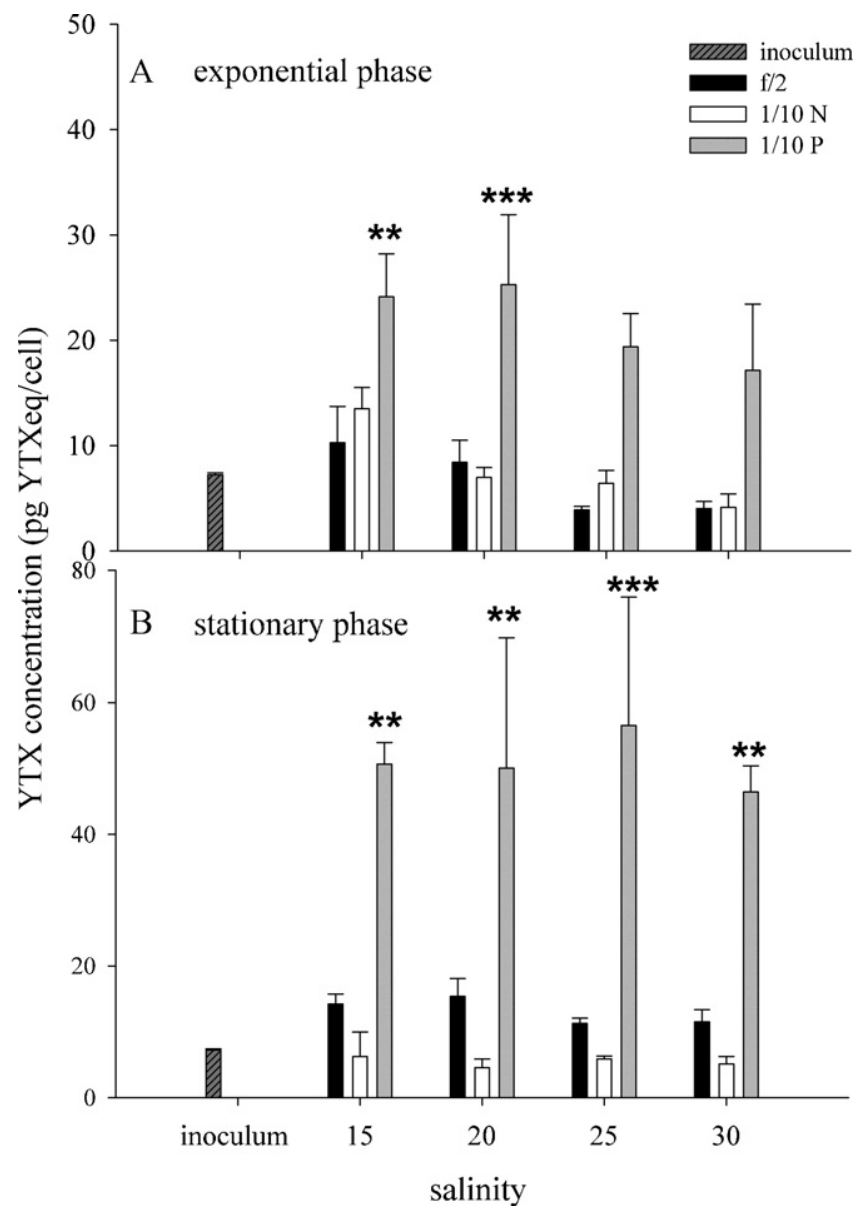

Fig. 5. Concentration of YTX $(m / z 1141.4>1061.5)$ in $P$. reticulatum $\left(15^{\circ} \mathrm{C}\right)$ in (a) the exponential and (b) the stationary phase; the error bars represent standard error $(n=3)$. Significant results were labelled with asterisks: ${ }^{*} P<0.05,{ }^{* *} P<0.01$, *** $P<0.001$

YTX cell quota of the inoculum at salinities of $15(P>0.01), 20$ $(P>0.01), 25(P>0.001)$ and $30(P>0.01)$ (Fig. 5b).

Cultivation at higher temperature $\left(20^{\circ} \mathrm{C}\right)$ led to an increase of YTX concentrations cell $^{-1}$ when grown at higher salinities. However, the YTX concentrations were low when cultures were grown at salinities of 15 and 20 at $20^{\circ} \mathrm{C}$. This was obvious for most of the samples during the exponential and stationary phase (Fig. 6a and $\mathrm{b})$. Generally, $1 / 10 \mathrm{~N}$ cultures contained the lowest and $1 / 10 \mathrm{P}$ cultures the highest YTX concentration cell $^{-1}$. Significant differences of YTX cell quota were observed in the stationary growth phase comparing the inoculum and $P$. reticulatum cells cultured at a salinity of 30 in $\mathrm{f} / 2$ medium $(P<0.05)$, as well as at salinities of 25 and 30 in $1 / 10 \mathrm{P}$ medium $(P<0.001)$. Comparing exponential to stationary growth phase significant differences were observed between $1 / 10 \mathrm{~N}$ media at a salinity of $15(P<0.05), 1 / 10 \mathrm{P}$ media at salinities of $20(P<0.05), 25(P<0.001)$, and $30(P<0.05)$.

The concentrations of both YTX and the YTX analogues (carboxyYTX and ketoYTX) were enhanced under P-limited conditions. Compared to the inoculum the concentrations of the YTX analogues decreased in the $\mathrm{f} / 2$ media, except that the concentration of YTX analogues increased in $f / 2$ medium at a salinity of 15 . Due to the lower concentration of YTXs and partly lower amount of cells resulting in an YTX cell quota below LOQ it was not possible to interpret detected amount of YTXs in the cells cultured at $20^{\circ} \mathrm{C}$. In addition, we detected differences in the pattern of YTXs under different limitations independent of the salinity (Fig. 7).

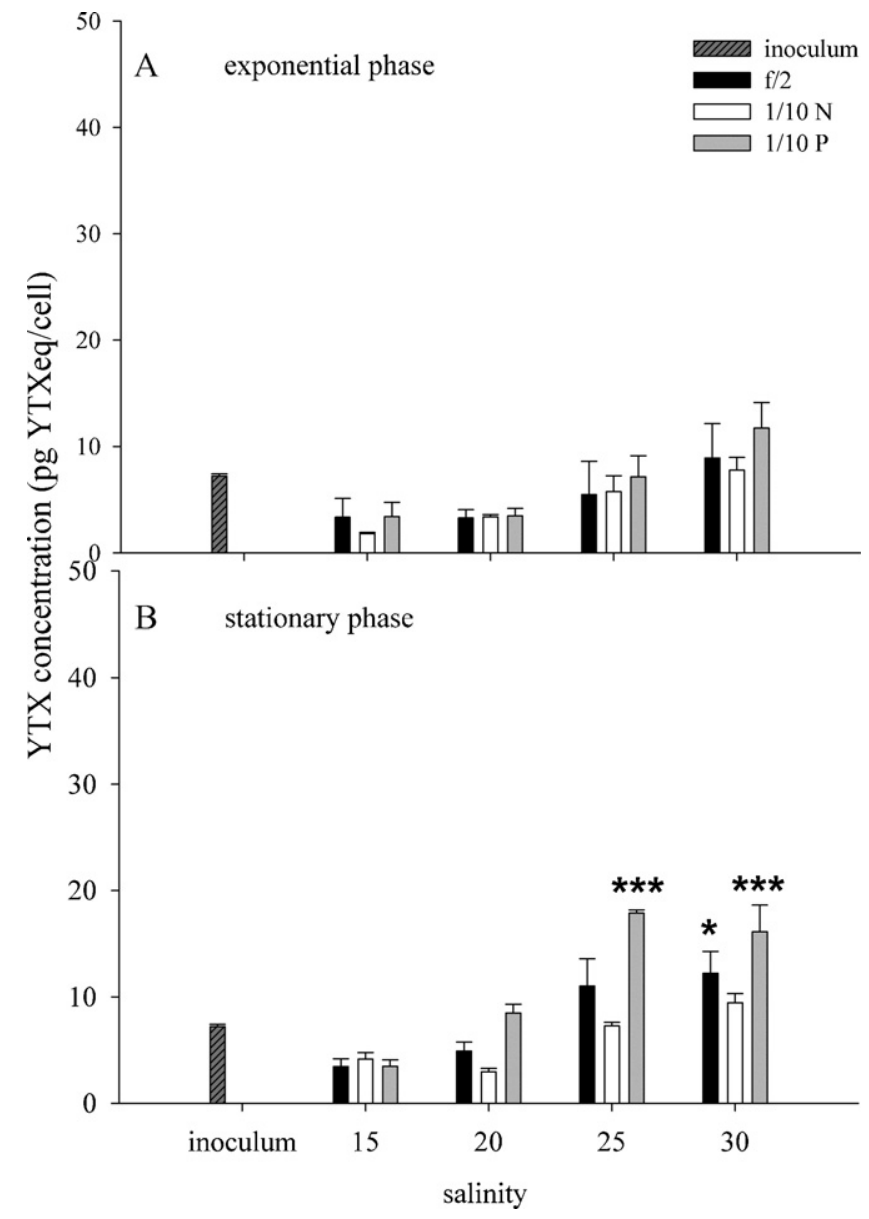

Fig. 6. Concentration of YTX $(m / z 1141.4>1061.5)$ in $P$. reticulatum $\left(20^{\circ} \mathrm{C}\right)$ in (a) the exponential and (b) the stationary phase; the error bars represent standard error $(n=3)$. Significant results were labelled with asterisks: ${ }^{*} P<0.05,{ }^{* *} P<0.01$, ${ }^{* * *} P<0.001$.

\subsection{Extracellular YTX concentration}

The YTX concentrations were calculated as YTX $\mathrm{ml}^{-1}$ filtrate. The results were normalized to the cell concentrations for comparison of intracellular and extracellular quota of YTX, which was found in the filtrate of all cultures. Generally, the concentration of YTX (normalized to the cell counts) in the filtrate was lower with lower cell concentrations, especially during the exponential growth phase. However, during the stationary phase the YTX concentration cell ${ }^{-1}$ in the filtrate increased in all samples. In addition, a slight decrease of the YTX cell quota was observed with increasing salinity. Higher temperature during cultivation resulted also in a partly different excretion of YTX (Fig. 8 and Table 2).

\section{Discussion}

$P$. reticulatum is common in different geographical areas all over the world and many reports exist about accumulation of YTX in several molluscan shellfish species (e.g. Aasen et al., 2005; Ciminiello et al., 1997, 2003; Finch et al., 2005; Krock et al., 2006; MacKenzie et al., 1998; Paz et al., 2004, 2006, 2007, 2008; Ramstad et al., 2001; Samdal et al., 2004; Satake et al., 1997, 1999, 2006; Suzuki et al., 2007; Yasumoto and Takizawa, 1997). The $P$. reticulatum strain used in this study was isolated in the North Sea and identified as YTX producer (Hoppenrath, 2004). Up to now no serious accumulation of YTXs in shellfish species was reported in the German Bight. However, the presence of $P$. reticulatum in the 


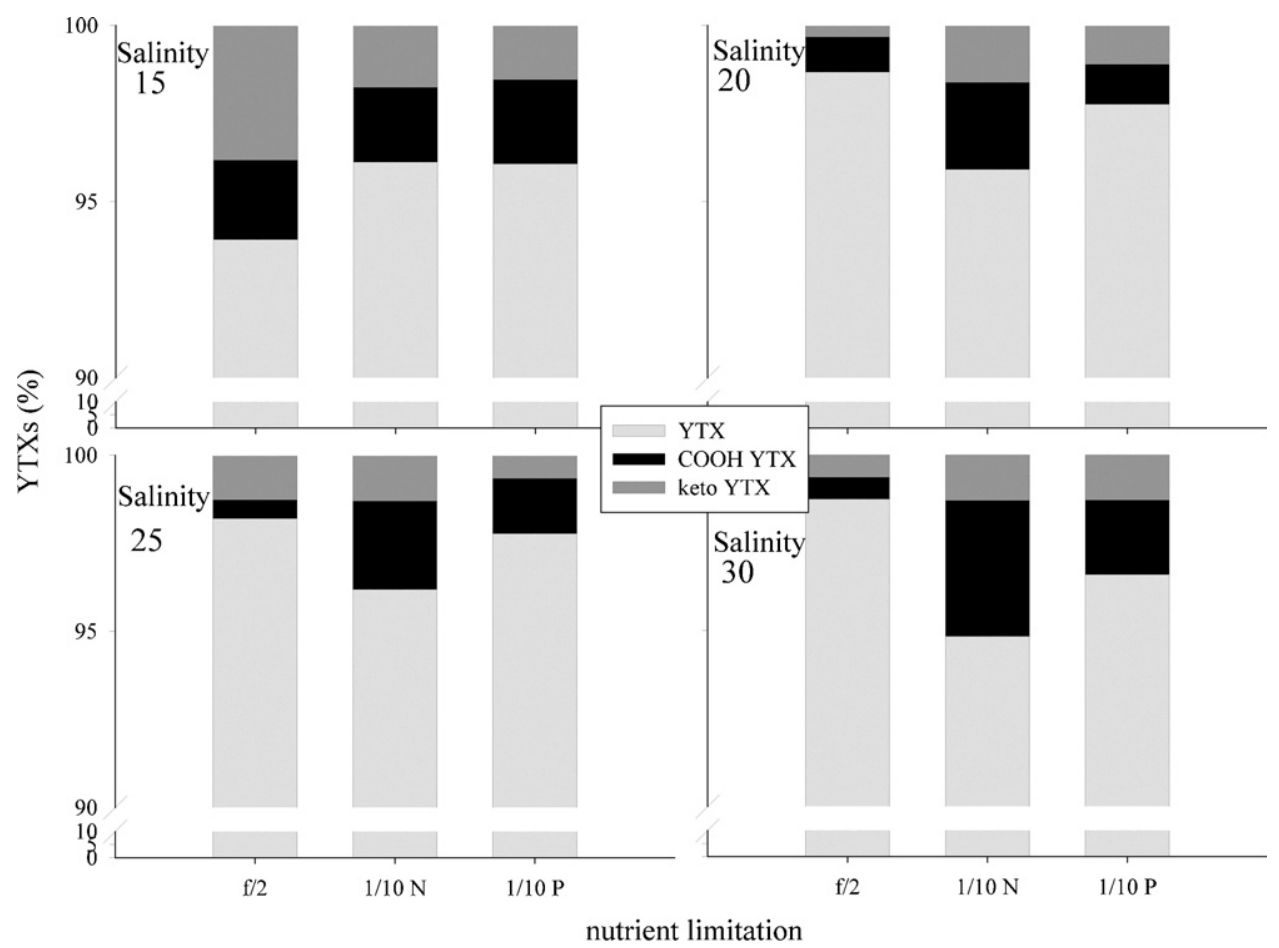

Fig. 7. Percentage of YTX and its analogues (COOH YTY and keto YTX) in the stationary phase $\left(15^{\circ} \mathrm{C}\right)$ at different salinities in dependence of the nutrient limitation.

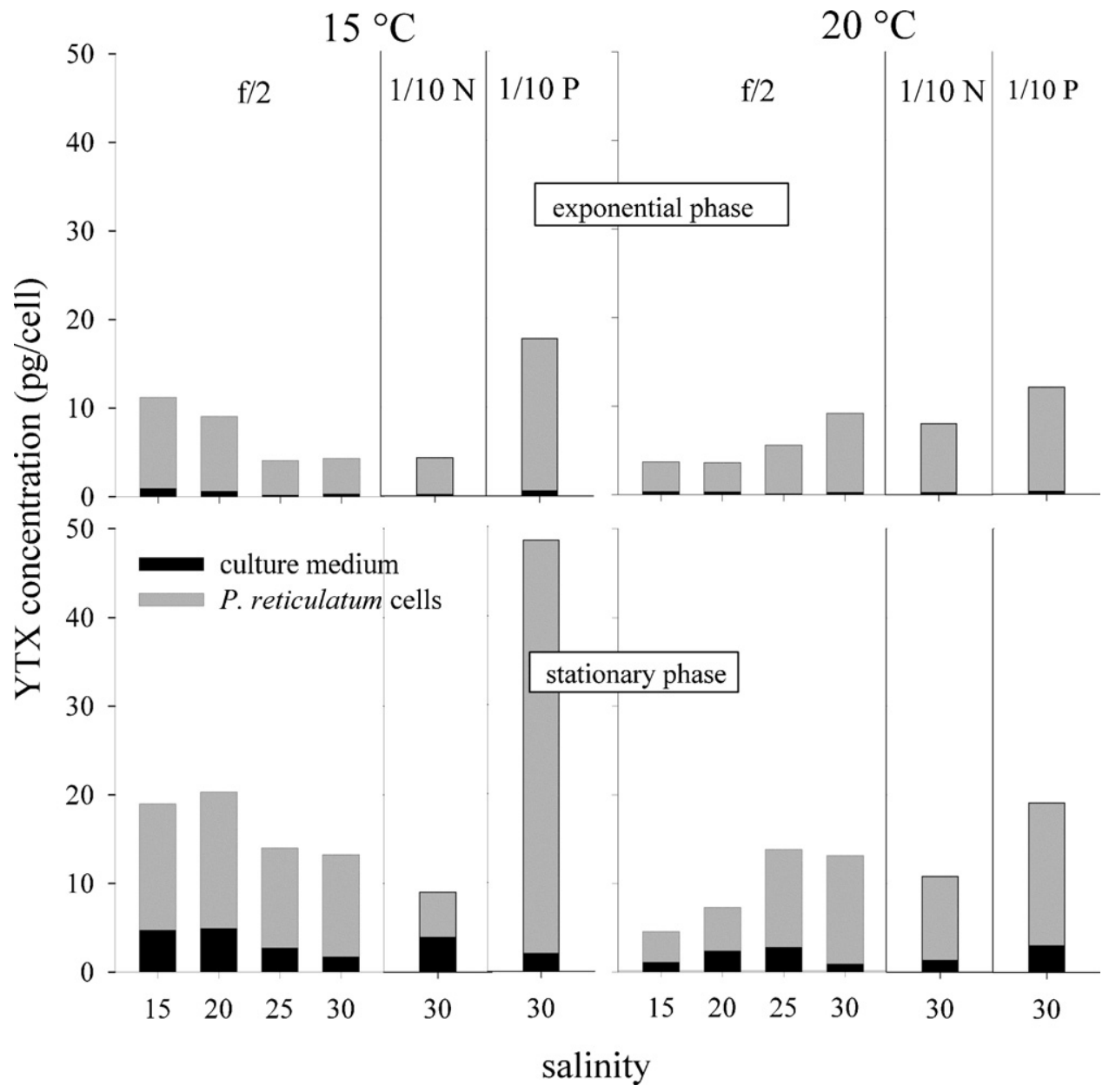

Fig. 8. Concentration of YTX $(m / z 1141.4>1061.5)$ in the culture filtrate $\left(15^{\circ} \mathrm{C}\right.$ and $\left.20^{\circ} \mathrm{C}\right)$ in the exponential and the stationary phase. Concentrations in the filtrate were related to the cells $/ \mathrm{ml}$ (as an indicator). 
Table 2

Percentage of YTX (\%) in cells of $P$. reticulatum and in the media filtrate in the exponential and the stationary phase.

\begin{tabular}{|c|c|c|c|c|c|c|c|}
\hline \multirow[t]{3}{*}{ Temperature $\left({ }^{\circ} \mathrm{C}\right)$} & \multirow[t]{3}{*}{ Salinity } & \multicolumn{6}{|c|}{ Percentage (\%) of YTX cell quota in the filtrate and YTX cell quota in cells of $P$. reticulatum } \\
\hline & & \multicolumn{2}{|l|}{ C } & \multicolumn{2}{|l|}{$1 / 10 \mathrm{~N}$} & \multicolumn{2}{|l|}{$1 / 10 \mathrm{P}$} \\
\hline & & Filtrate & Cells & Filtrate & Cells & Filtrate & Cells \\
\hline \multirow[t]{10}{*}{15} & Expone & & & & & & \\
\hline & 15 & 8 & 92 & & & & \\
\hline & 20 & 7 & 93 & & & & \\
\hline & 25 & 4 & 96 & & & & \\
\hline & 30 & 7 & 93 & 4 & 96 & 3 & 97 \\
\hline & Stationa & & & & & & \\
\hline & 15 & 25 & 75 & & & & \\
\hline & 20 & 24 & 76 & & & & \\
\hline & 25 & 19 & 81 & & & & \\
\hline & 30 & 13 & 87 & 43 & 57 & 4 & 96 \\
\hline \multirow[t]{10}{*}{20} & Expone & & & & & & \\
\hline & 15 & 10 & 90 & & & & \\
\hline & 20 & 10 & 90 & & & & \\
\hline & 25 & 2 & 98 & & & & \\
\hline & 30 & 3 & 97 & 3 & 97 & 3 & 97 \\
\hline & Stationa & & & & & & \\
\hline & 15 & 24 & 76 & & & & \\
\hline & 20 & 33 & 67 & & & & \\
\hline & 25 & 20 & 80 & & & & \\
\hline & 30 & 7 & 93 & 12 & 88 & 16 & 84 \\
\hline
\end{tabular}

North Sea plankton necessitates investigations with focus on the potential risk of blooms of this dinoflagellate.

$P$. reticulatum, isolated from the North Sea displays a growth optimum at $15^{\circ} \mathrm{C}$ in $\mathrm{f} / 2$ medium (Fig. 2a). In contrast, at higher temperature (in this case $20^{\circ} \mathrm{C}$ ) growth decreased considerably (Fig. 2b). Hence, a P. reticulatum bloom with high cell densities is more likely to occur during the spring or early summer months. Up to now only low amounts of $P$. reticulatum were found in the German bight.

Dinoflagellates are capable of storing $\mathrm{N}$ and $\mathrm{P}$ in intracellular pools for use during times of deficiency (Cembella et al., 1984; Dortch et al., 1984). The low chlorophyll a concentration (Fig. 4), which was detectable in all $\mathrm{N}$-deficient cultures, indicated that those cells were indeed N deficient (Boyer et al., 1987). Beside temperature and nutrient-availability salinity is a factor influencing the growth of $P$. reticulatum, which is known to grow in a wide range of salinities (Guerrini et al., 2007; Koike et al., 2006). In our experiments the growth of $P$. reticulatum decreased with lower salinity and is close to zero at salinities underneath a salinity of 15.

Eutrophication adherent with alteration of the composition of nutrients could enhance the chances for accelerated growth of harmful algal bloom (HAB) species (Anderson et al., 2002). In this context, rising anthropogenic effects together with simultaneous climate change have been reported worldwide and also in the North Sea (Edwards et al., 2006; Wiltshire et al., 2008). N and P are important nutrients for the growth of microalgae, where upon microalgae are known to require $\mathrm{N}$ in a higher quantity compared to $\mathrm{P} . \mathrm{N}$ is mostly limiting factor with regard to phytoplankton growth in marine and estuary waters albeit $\mathrm{P}$ can also be the limiting factor under large $\mathrm{N}$ input (Anderson et al., 2002). Therefore, changes of nutrient composition or temperature of the North Sea during the seasons lead to characteristic differences in growth of the phytoplankton species within HABs. However, increasing temperature of the water of the North Sea caused by climate change would not lead to a higher risk for a bloom of $P$. reticulatum. In the North Sea phosphorous (P) seems to be the first limiting nutrient in spring and nitrogen $(N)$ in summertime (Peeters et al., 1991). A higher input of nutrients during the spring caused by eutrophication could result in increased phytoplankton growth and a possible P-limitation at the end of the bloom stopping cell division can cause very high YTX concentrations cell $^{-1}$.

\subsection{YTX concentration in $P$. reticulatum cells}

From our experiments it is evident that for $P$. reticulatum a clear correlation between the total concentration of YTXs and nutrient limitation can be observed (Fig. 5). Whereas the cell quota of YTX generally increased in the following order: $1 / 10 \mathrm{~N}<\mathrm{f} / 2<1 / 10 \mathrm{P}$ media. Unfavourable growth conditions can induce changes of cell size, morphology and earlier entrance into the stationary growth phase. This effect can correlate with the formation of temporary resting stages (hypnocygotes) and such cells were found in the $\mathrm{f} / 2$ media (at lower salinities) and in 1/10 $\mathrm{P}$ media, whereby the occurrence was partly correlated with an increased production of YTXs. A deformation of cells was noticeable at higher temperatures, especially in the $\mathrm{f} / 2$ media at higher salinities.

Recently, it was reported that the YTX concentration increased with increasing salinity (Guerrini et al., 2007). After normalization of the YTX cell quota to the cell size, this YTX profile was not observed during the exponential growth phase but it was found during the stationary phase (Fig. 9a and b). Generally, cell quotas of YTXs cultured at $20^{\circ} \mathrm{C}$ were lower compared to $15^{\circ} \mathrm{C}$. At $20^{\circ} \mathrm{C}$ the cell quotas of YTXs increased with increasing salinity during the stationary phase, whereby the influence of limitations was not obvious (Fig. 9c and d). Possibly higher temperatures inhibited the toxin production which is not in agreement with observations by Guerrini et al. (2007) and Paz et al. (2006). But the conditions of the cultures were not optimal at $20{ }^{\circ} \mathrm{C}$ and therefore, we suppose that YTX production is associated to a functioning metabolism. Especially in $1 / 10 \mathrm{P}$ medium cells at $15^{\circ} \mathrm{C}$ a longer cultivation time caused higher YTX cell quota, which was also observed when the size was included. Because P-limitation is known to stop the cell division in other dinoflagellates without die back of the cells, an accumulation of YTX under ongoing metabolism is likely, since it is established for other species that P-limitation can cause accumulation of several fatty acids and those are known to have a similar precursor as polyketides.

Specific environmental conditions as changes of the salinity or nutrient limitation can lead to an altered toxin production or altered toxin patterns in dinoflagellates (Anderson et al., 1990; 


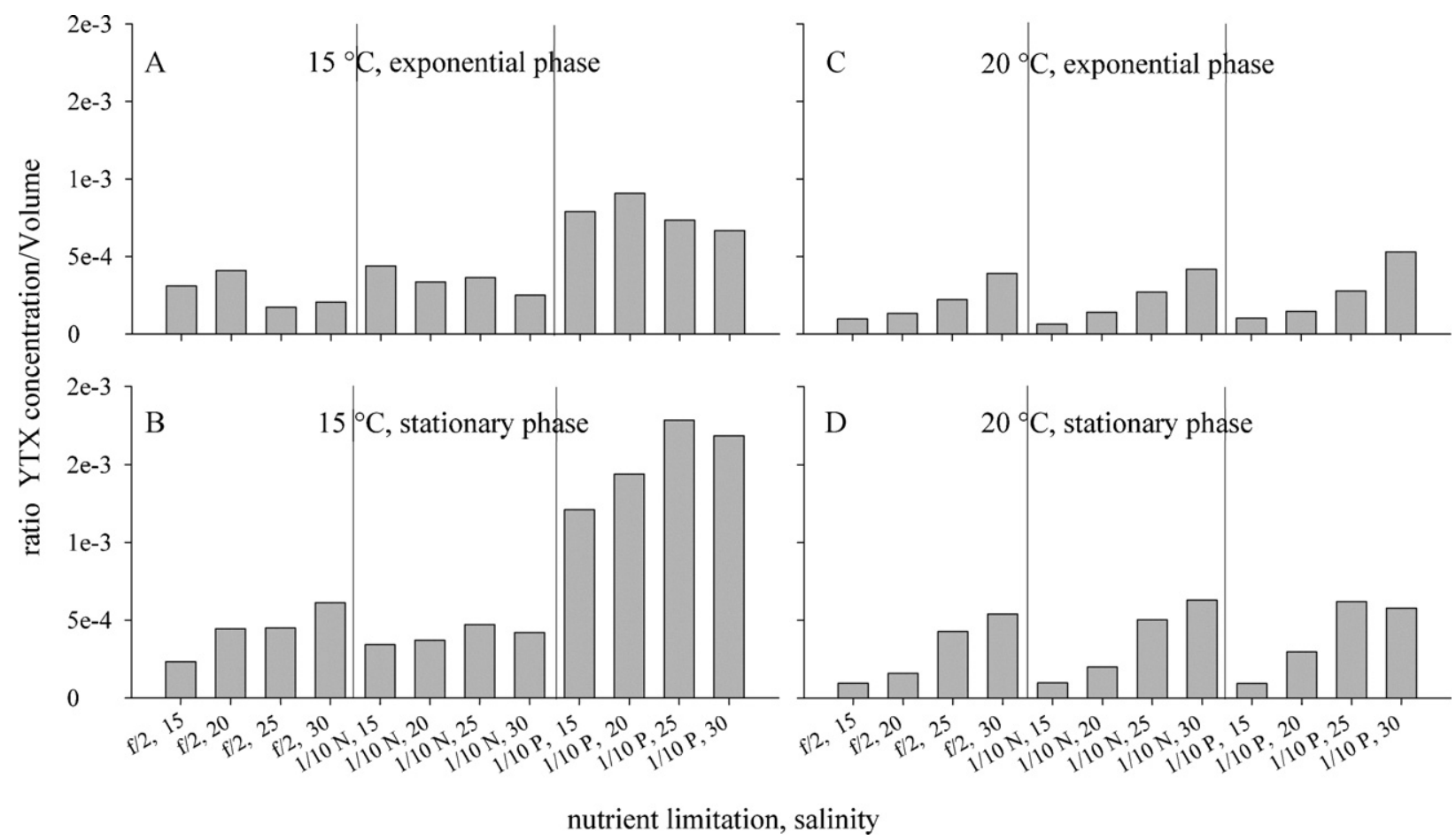

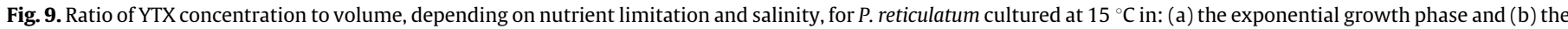
stationary phase and at $20^{\circ} \mathrm{C}$ in: (c) the exponential growth phase and (d) the stationary phase.

Beani et al., 2000; Boyer et al., 1987; Grzebyk et al., 2003; Maier Brown et al., 2006; Roeder et al., 2010). Hence, the formation of Brevetoxins ( $\mathrm{PbTx}$ ) was investigated under various salinities and the data revealed that the influence of such parameters is very complex and it was evident that PbTx concentrations were always higher in the stationary phase (Maier Brown et al., 2006). The production of paralytic shellfish poisoning (PSP) toxins (e.g. by Alexandrium spp.) is higher at low phosphorus concentrations (Anderson et al., 1990; Beani et al., 2000; Boyer et al., 1987; Grzebyk et al., 2003) and low salinity values (Hwang and Lu, 2000) whereas N-limitation can cause a decrease of toxin concentration (Boyer et al., 1987). The same effect on toxicity caused by lower salinity was reported in a work about toxin production of the raphidophycean flagellate Heterosigma akashiwo (Haque and Onoue, 2002). Those examples are in large part consistent with our experiment and illustrate the need for the elucidation of a potential risk for toxic dinoflagellate events in the North Sea and other marine environments.

It is still unknown why polyether toxins are produced by several dinoflagellate species and the question remains why in one strain nutrient limitation leads to an increased toxin quota per cell but not in the other. Hence, other strains from different locations should be studied concerning the influence of nutrients on the toxin formation. In addition more investigations are needed to discover the dynamics and mechanisms concerning toxin formation in marine dinoflagellates during HABs.

\subsection{Extracellular YTX concentration}

In several studies it was found that YTX was released into the medium and several reasons have been suggested (Mitrovic et al., 2005; Paz et al., 2004, 2006, 2007). Data published by Paz et al. $(2004,2006,2007)$ showed that the total toxin amount of YTX in some culture filtrates reaches a considerable amount up to $38 \%$ of total YTX concentrations. During our experiments YTX was detected in the filtrate in low concentrations during the exponential growth period. It was evident, that the measured YTX found in the culture media increased significantly during the stationary phase. Obviously, the release of YTX in the media depends on the salinity and on nutrient availability. Guerrini et al. (2007) found that the release of YTX into the culture media seems to be higher under $\mathrm{N}$-limitation, which was observable in our 1/10 $\mathrm{N}$ cultures at $15^{\circ} \mathrm{C}$.

We suppose that the detected YTX in the filtrate is caused by leakage from disintegrated cells. This hypothesis is supported by increasing YTX concentrations in the stationary phase and by the higher concentrations in cultures with unfavourable conditions. The percentage of intracellular to extracellular YTX in 1/10 P cultures did not change during culturing. Therefore, it is evident that less YTX was released into the medium in 1/10 P cultures. Furthermore, $1 / 10 \mathrm{P}$ cells cultured at $15{ }^{\circ} \mathrm{C}$ contained a high cell quota of YTX in the late stationary phase caused by the putative entrance into a "temporary resting stage". In addition the assumption that lower YTX concentrations in the filtrates are caused by less disintegrated cells, supports the theory that resting stages were formed and high YTX cell quotas could be a product of ongoing metabolism in those P-limited cells of $P$. reticulatum (see Figs. 5 and 9 and Table 2).

\section{Conclusion}

The strain of $P$. reticulatum under investigation during this study showed a good growth at salinities in the range of salinity of 20-30, with strong influence of water temperature and of nutrient limitation on the formation of YTXs. Generally, N-limited cultures displayed the lowest and P-limited cultures the highest YTX cell quota. Lower salinities caused a higher volume of the cell accompanied by an increase of YTX concentration. Summarizing it can be stated that the higher risk for toxic $P$. reticulatum blooms in the North Sea exists during a bloom in spring with P-limitation at the end of the bloom. 


\section{References}

Aasen, J., Samdal, I., Miles, C.O., Dahl, E., Briggs, L., Aune, T., 2005. Yessotoxins in Norwegian blue mussels (Mytilus edulis): uptake from Protoceratium reticulatum, metabolism and depuration. Toxicon 45, 265-272.

Anderson, D.M., Kulis, D.M., Sullivan, J.J., Hall, S., Lee, C., 1990. Dynamics and physiology of saxitoxin production by the dinoflagellates Alexandrium spp. Mar. Biol. 104, 511-524.

Anderson, D.M., Glibert, P.M., Burkholder, J.M., 2002. Harmful algal blooms and eutrophication: nutrient sources, composition, and consequences. Estuaries 25, 704-726.

Beani, L., Bianchi, C., Guerrini, F., Marani, L., Pistocchi, R., Tomasini, M.C., Ceredi, A. Milandri, A., Poletti, R., Boni, L., 2000. High sensitivity bioassay of paralytic (PSP) and amnesic (ASP) algal toxins based on the fluorimetric detection of $\left[\mathrm{Ca}^{2+}\right]_{\mathrm{i}}$ in rat cortical primary cultures. Toxicon 38, 1283-1297.

Boyer, G.L., Sullivan, J.J., Andersen, R.J., Harrison, P.J., Taylor, F.J.R., 1987. Effects of nutrient limitation on toxin production and composition in the marine dinoflagellate Protogonyaulax tamarensis. Mar. Biol. 96, 123-128.

Cembella, A.D., Antia, N.J., Harrison, P.J., 1984. The utilization of inorganic and organic phosphorus compounds as nutrients by eukaryotic microalgae: a multidisciplinary perspective. Part 1. Crit. Rev. Microbiol. 10, 317-391.

Ciminiello, P., Fattorusso, E., Forino, M., Poletti, R., Satake, M., Viviani, R., Yasumoto T., 1997. Yessotoxin in mussels of the northern Adriatic Sea. Toxicon 35, 177183.

Ciminiello, P., Dell'Aversano, C., Fattorusso, E., Forino, M., Magno, S., Guerrini, F. Pistocchi, R., Boni, L., 2003. Complex yessotoxins profile in Protoceratium reticulatum from north-western Adriatic Sea revealed by LC-MS analysis. Toxicon 42, 7-14.

Dortch, Q., Clayton, J.R., Thoresen, S.S., Ahmed, S.I., 1984. Species differences in accumulation of nitrogen pools in phytoplankton. Mar. Biol. 81, 237-250.

Draisci, R., Ferretti, E., Palleschi, L., Marchiafava, C., Poletti, R., Milandri, A., Ceredi, A. Pompei, M., 1999. High levels of yessotoxin in mussels and presence of yessotoxin and homoyessotoxin in dinogflagellates of the Adriatic Sea. Toxicon 37, 1187-1193.

Edwards, M., Johns, D.G., Leterme, S.C., Svendsen, E., Richardson, A.J., 2006. Regiona climate change and harmful algal blooms in the northeast Atlantic. Limnol. Oceanogr. 51, 820-829.

Eiki, K., Satake, M., Koike, K., Ogata, T., Mitsuya, T., Oshima, Y., 2005. Confirmation of yessotoxin production by the dinoflagellate Protoceratium reticulatum in Mutsu Bay. Fish. Sci. 72, 633-638.

Finch, S.C., Wilkins, A.L., Hawkes, A.D., Dwayne, J.J., MacKenzie, A.L., Beuzenberg, V. Quilliam, M.A., Olsen, C.D., Samdal, I.A., Aasen, J., Selwood, A.I., Cooney, J.M. Sandvik, M., Miles, C.O., 2005. Isolation and identification of (44-R,S)-44,55 dihydroxyyessotoxin from Protoceratium reticulatum, and its occurrence in extracts of shellfish from New Zealand, Norway and Canada. Toxicon 46, $160-170$.

Gallardo Rodríguez, J.J., Sánchez Miron, A., Del Carmen Ceron Garcia, M., Hassan Belarbi, H., García Camacho, F., Chisti, Y., Molina Grima, E., 2009. Macronutrients requirements of the dinoflagellate Protoceratium reticulatum. Harmful Algae 8, 239-246.

Grzebyk, D., Béchemin, C., Ward, C.J., Vérité, C., Codd, G.A., Maestrini, S.Y., 2003. Effects of salinity and two coastal waters on the growth and toxin content of the dinoflagellate Alexandrium minutum. J. Plankt. Res. 25, 1185-1199.

Guerrini, F., Ciminiello, P., Dell'Aversano, C., Tartaglione, L., Fattorusso, E., Boni, L., Pistocchi, R., 2007. Influence of temperature, salinity and nutrient limitation on yessotoxin production and release by the dinoflagellate Protoceratium reticulatum in batch-cultures. Harmful Algae 6, 707-717.

Guillard, R.R., 1973. Division rates. In: Stein, J.R. (Ed.), Handbook of Phycological Methods-Culture Methods and Growth Measurements. Cambridge University Press, London, pp. 289-311.

Guillard, R.R., 1975. Culture of phytoplankton for feeding marine invertebrates. In: Smith, W.L., Chanley, M.H. (Eds.), Culture of Marine Invertebrate Animals. Plenum Press, New York, pp. 29-60.

Hansen, G., Moestrup, Ø., Roberts, K.R., 1997. Light and electron microscopical observations on Protoceratium reticulatum (Dinophyceae). Arch. Protistenkd. $147,381-391$.

Haque, S.M., Onoue, Y., 2002. Effects of salinity on growth and toxin production of a noxious phytoflagellate, Heterosigma akashiwo (Raphidophyceae). Bot. Mar. 45, 356-363.

Hoppenrath, M., 2004. A revised checklist of planktonic diatoms and dinoflagellates from Helgoland (North Sea, German Bight). Helgol. Mar. Res. 58, $243-$ 251.

Hoppenrath, M., Elbrächter, M., Drebes, G., 2009. Marine phytoplankton. Selected microphytoplankton species from the North Sea around Helgoland and Sylt. In: Kleine Senckenberg-Reihe 49, E. Schweizerbart'sche Verlagsbuchhandlung (Nägele \& Obermiller), Stuttgart, 264 pp.

Howard, M.D.A., Silver, M., Kudela, R.M., 2008. Yessotoxin detected in mussel (Mytilus californicus) and phytoplankton samples from the U.S. west coast. Harmful Algae 7, 646-652.

Hwang, D.F., Lu, Y.H., 2000. Influence of environmental and nutritional factors on growth, toxicity, and toxin profile of dinoflagellate Alexandrium minutum. Toxicon 38, 1491-1503.

Koike, K., Horie, Y., Suzuki, T., Kobiyama, A., Kurihara, K., Takagi, K., Kaka, S.-N., Oshima, Y., 2006. Protoceratium reticulatum in northern Japan: environmental factors associated with seasonal occurrence and related contamination of yessotoxin in scallops. J. Plankt. Res. 28, 103-112.
Krock, B., Alpermann, T., Tillmann, U., Pitcher, G.C., Cembella, A.D., 2006. Yessotoxin (YTX) profiles from cultures and plankton samples of the marine dinoflagellates Protoceratium reticulatum and Gonyaulax spinifera. In: Moestrup, Ø. (Editor-in Chief). Proceedings of the 12th International Conference on Harmful Algae, Copenhagen, Denmark, September 4-8, 2006. International Society for the Study of Harmful Algae (ISSHA) and the Intergovernmental Oceanographic Commission (IOC of UNESCO), Copenhagen, pp. 303-305.

Krock, B., Seguel, C.G., Valderrama, K., Tillmann, U., 2009. Pectenotoxins and yessotoxin from Arica Bay, North Chile as determined by tandem mass spectrometry. Toxicon 54, 364-367.

MacKenzie, L., Trumann, P., Yasumoto, T., 1998. Dinoflagellate blooms and associated DSP-toxicity in shellfish in New Zealand. In: Reguera, B., Blanco, J., Fernández, M.L., Wyatt, T. (Eds.), Harmful Algae. Xunda de Galacia, Spain and Intergovernmantal Oceanographic Commission of Unesco, Paris, pp. 74-77.

Maier Brown, A.F., Dortch, Q., Van Dolah, F.M., Leighfield, T.A., Morrison, W., Thessen, A.E., Steidinger, K., Richardson, B., Moncreiff, C.A., Pennock, J.R. 2006. Effect of salinity on the distribution, growth, and toxicity of Karenia spp. Harmful Algae 5, 199-212.

Miles, C.O., Wilkins, A.L., Jensen, D.J., Cooney, J.M., Quilliam, M.A., Aasen, J., MacKenzie, A.L., 2004. Isolation of 41a-homoyessotoxin and the identification of 9methyl-41ahomoyessotoxin and Nor-ring A-yessotoxin from Protoceratium reticulatum. Chem. Res. Toxicol. 17, 1414-1422.

Miles, C.O., Samdal, I.A., Aasen, J.A.G., Jensen, D.J., Quilliam, M.A., Petersen, D., Briggs, L.M., Wilkins, A.L., Rise, F., Cooney, J.M., MacKenzie, J.A., 2005a. Evidence for numerous analogs of yessotoxin in Protoceratium reticulatum. Harmful Algae 4, 1075-1091.

Miles, C.O., Wilkins, A.L., Hawkes, A.D., Selwoold, A.I., Jenen, D.J., Munday, R., Cooney, J.M., Beuzenberg, V., 2005b. Polyhydroxylated amide analogs of yessotoxin from Protoceratium reticulatum. Toxicon 45, 61-71.

Miles, C.O., Wilkins, A.L., Hawkes, A.D., Selwood, A.I., Jensen, D.J. Cooney, J.M., Beuzeberg, V., MacKenzie, A.L., 2006a. Identification of 45-hydroxy-46,47-dinoryessotoxin, 44-oxo-45,46,47-trinoryessotoxin, and 9-methyl-42,43,44,45,46,47,55heptanor-38-en-41-oxoyessotoxin, and partial characterization of some minor yessotoxins, from Protoceratium reticulatum. Toxicon 47, 229-240.

Miles, C.O., Wilkins, A.L., Selwood, A.I., Hawkes, A.D., Jensen, D.J., Cooney, J.M., Beuzenberg, V., MacKenzie, A.L., 2006b. Isolation of Yessotoxin 32-O-[ $\beta$-Larabinofuranosyl-( $\left.5^{\prime} \rightarrow 1^{\prime \prime}\right)-\beta$-L-arabinofuranoside] from Protoceratium reticulatum. Toxicon 47, 510-516.

Mitrovic., S.M., Fernández Amandi, M., McKenzie, L., Furey, A., James, K.J., 2004. Effects of selenium, iron and cobalt addition to growth and yessotoxin production of the toxic marine dinoflagellate Protoceratium reticulatum in culture. J. Exp. Mar. Biol. Ecol. 313, 337-351.

Mitrovic, S.M., Hamilton, B., MacKenzie, L., Furey, A., James, K.J., 2005. Persistence of yessotoxin under light and dark conditions. Mar. Environ. Res. 60, 397-401.

Murata, M., Kumakai, M., Soo Lee, J., Yasumoto, T., 1987. Isolation and structure of yessotoxin, a novel polyether compound implicated in diarrhetic shellfish poisoning. Tetrahedron Lett. 28, 5869-5872.

Paz, B., Riobó, P., Fernández, M.L., Fraga, S., Franco, J.M., 2004. Production and release of yessotoxins by the dinoflagellates Protoceratium reticulatum and Lingulodinium polyedrum in culture. Toxicon 44, 251-258.

Paz, B., Riobó, P., Souto, M.L., Gil, L.V., Norte, M., Fernandez, J.J., Franco, J.M., 2006. Detection and identification of glycoyessotoxin A in a culture of the dinoflagellate Protoceratium reticulatum. Toxicon 48, 611-619.

Paz, B., Riobó, P., Ffernández, M.L., Fraga, S., Franco, J.M., Ramilo, I., Franco, J.M., 2007. Yessotoxins profile in strains of Protoceratium reticulatum from Spain and USA. Toxicon 50, 1-17.

Paz, B., Daranas, A.H., Norte, M., Riobó, P., Franco, J.M., Fernández, J.J., 2008. Yessotoxins, a group of marine polyether toxins: an overview. Marine Drugs $6,73-102$.

Peeters, J.V.H., Haas, H.A., Peperzak, L., Weitsteyn, L.P.M.J., 1991. Limiting factors for phytoplankton in the North Sea. Water Sci. Technol. 24, 261-267.

Ramstad, H., Hovgaard, P., Yasumoto, T., Larsen, S., Aune, T., 2001. Monthly variations in diarrethic toxins and yessotoxin in shellfish from coast to the inner part of the Sognefjord, Norway. Toxicon 39, 1035-1043.

Rhodes, L., McNabb, P., De Salas, M., Briggs, V., Beuzenberg V., Gladstone, M. 2006. Yessotoxin production by Gonyaulax spinifera. Harmful Algae 5, 148-155.

Riccardi, M., Guerrini, F., Roncarati, F., Milandri, A., Gangini, M., Rigozzi, S., Riccardi, E., Ceredi, A., Ciminiello, P., Dell'Aversano, C., Fattorusso, E., Forino, M., Tartaglione, L., Pistocchi, R., 2009. Gonyaulax spinifera from the Adriatic Sea: toxin production and phylogenetic analysis. Harmful Algae 8, 279-290.

Röder, K., Fritz, N., Gerdts, G., Luckas, B., 2011. Accumulation and depuration of yessotoxin in two bivalves. J. Shellfish Res. 30, 167-175.

Roeder, K., Erler, K., Kibler, S., Tester, P., Van The, H., Nguyen-Ngoc, L., Gerdts, G., Luckas, B., 2010. Characteristic profiles of Ciguatera toxins in different strains of Gambierdiscus spp. Toxicon 56, 731-738.

Samdal, I.A., Naustvoll, L.J., Olseng, C.D., Briggs, L.R., Miles, C.O., 2004. Use of ELISA to identify Protoceratium reticulatum as a source of yessotoxin in Norway. Toxicon $44,75-82$

Satake, M., Terawawa, K., Kadowaki, Y., Yasumoto, T., 1996. Relative configuration of yessotoxin and isolation of two new analogues from toxic scallops. Tetrahedron Lett. 37, 5955-5958.

Satake, M., MacKenzie, L., Yasumoto, T., 1997. Identification of Protoceratium reticulatum as biogenetic origin of yessotoxin. Nat. Toxins 5, 164-167.

Satake, M., Ichimura, T., Sekiguchi, K., Yoshimatsu, S., Oshima, Y., 1999. Confirmation of yessotoxin and 45,46,47-trinoryessotoxin production by Protoceratium reticulatum in Japan. Nat. Toxins 7, 147-150. 
Satake, M., Eiki, M., Ichimura, T., Ota, S., Sekiguchi, K., Oshima, Y., 2006. Structure of 45,46,47-trinorhomoyessotoxin, a new analog, from Protoceratium reticulatum which represents the first detection of a homoyessotoxin analog in Japan. Harmful Algae 5, 731-735.

Sieracki, C.K., Sieracki, M.E., Yentsch, C.S., 1998. An imaging-in-flow system for automated analysis of marine microplankton. Mar. Ecol. Prog. Ser. 168, 285296.

Suzuki, T., Horie, Y., Koike, K., Satake, M., Oshima, Y., Iwataki, M., Sadaaki, Y., 2007. Yessotoxin analogues in several strains of Protoceratium reticulatum in Japan determined by liquid chromatography-hybrid triple quadrupole/linear ion trap mass spectrometry. J. Chromatogr. A 1142, 172-177.

Tubaro, A., Sidari, L., Della Loggia, R., Yasumoto, T., 1998. Occurence of homoyessotoxin in phytoplankton and mussels from Northern Adriatic Sea. In: Reguera, B., Blanco, J., Fernandez, M.L., Wyatt, T. (Eds.), Harmful Algae. Xunta de Galicia and Intergovernmental Oceanographic Commission of UNESCO, Grafisant, Santiago de Compostela, pp. 470-472.

Von Stosch, H.A., 1969. Dinoflagellaten aus der Nordsee I. Über Cachonina niei Loeblich (1968), Gonyaulax grindleyi Reinecke (1967) und eine Methode zur Darstellung von Peridineenpanzern. Helgol. Wiss. Meeresunters. 19, 558-568.

Wiltshire, K.H., Malzahn, A.M., Greve, W., Wirtz, K., Janisch, S., Mangelsdorf, P. Manly, B., Boersma, M., 2008. Resilience of North Sea phytoplankton spring bloom dynamics: an analysis of long-term data at Helgoland Roads. Limnol. Oceanogr. 53, 1294-1302.

Woloszynska, H.J., 1928. Dinoflagellatae der polnischen Ostsee sowie der an der Piasnica gelegenen Sümpfe. Archwm. Hydrobiol. Ryb. 3, 155-278.

Yasumoto, T., Takizawa, A., 1997. Fluorometric measurement of yessotoxins in shellfish by high-pressure liquid chromatography. Biosci. Biotechnol. Biochem. 61, 1775-1777. 